American Journal of Applied Sciences 8 (3): 206-211, 2011

ISSN 1546-9239

(C) 2010 Science Publications

\title{
Performance of Hevea brasiliensis on Haplic Ferralsol as Affected by Different Water Regimes
}

\author{
Shafar Jefri Mokhatar, Noordin Wan Daud and Nazera Arbain \\ Department of Crop Science, Faculty of Agriculture, University Putra Malaysia, \\ 43400 UPM Serdang, Selangor, Malaysia
}

\begin{abstract}
Problem statement: Rubber has been grown more than a century in South East Asia, who has been the largest producer of natural rubber. Demand of natural rubber increases steadily due to increasing demand particularly from developing countries. Water has been a limited and invaluable resource especially in agriculture. This resource has to be used wisely and there is a need for a detailed study pertaining to water requirement of rubber plants. This study provides details about rubber plants growth in relation to water stress. Approach: Two new latex timber clones from Malaysia Rubber Board (MRB), RRIM 2005 and RRIM 3001 were used in this study with soil from Haplic Ferralsol used as planting media. Five levels of treatment were used; plants irrigated for every 2, 5, 10 and 15 days and everyday which acted as control. The experimental design used was a Completely Randomized Block Design (RCBD) with four replications. Results: Results showed treatment well watered for clone RRIM 2025 (T6) had most the turgidity with high mean value in stomata conductance and chlorophyll content. RRIM 2025 also more resist to water stress compared to RRIM 3001. All plants in treatments with extreme different in water regimes cannot survive and dead due to severe stress. Conclusion: This study found rubber clones RRIM 2025 and RRIM 3001 cannot survive with acute deficiency of water. Rubber cannot be planted in dry areas with low water regimes which will retard the plant growth and plant will die under severe water stress.
\end{abstract}

Key words: Hevea brasiliensis, rubber tree, water regimes, water stress, photosynthesis rate, haplic ferralsol, rubber clones

\section{INTRODUCTION}

Rubber tree (Hevea brasiliensis) has been discovered since fifteenth century, when Christopher Columbus discovered the Americas. Since then, several usage of rubber has been discovered from time to time. Rubber tree is well known for its latex production and now as timber. Rubberwood have been used for furniture making (Malaysian Rubber Board, 2009).Currently, suitable planting area decreases and to overcome this problem, planting of rubber in other region is necessary.

RRIM 2025 and RRIM 3001 are classified as Latex Timber Clones, which can produce high yield of latex and timber. Clones are group of plants which are genetically identical and are derived from a single parent. For vegetative propagated plants like Hevea brasiliensis, clones are normally being mass propagated by bud grafting (Malaysian Rubber Board, 2009).

Water also have been a limited resource in agriculture and its must be use efficiently. Water also one of the most important limiting factors in plant growth other than Nitrogen (Sajedi et al., 2009; Mirakhori et al., 2009; Schindler et al., 2007; Xu and $\mathrm{Yu}, 2006$; Fan and Zhang, 2000). In plant relations, determination of the water requirement of plant is important for agriculture in dry regions (Gholizadeh et al., 2010; Fuller and Harhay, 2010). Soil can process and contain considerable amounts of water. They can take in water and will keep doing so until they are full, or the rate at which they can transmit water into and through, the pores is exceeded. Available Water Content (AWC) is the range of available water that can be stored in soil and be available for growing crops (Veihmeyer and Hendrickson, 1927). In order to get water availability, principle of water retention is used. Soil water retention is often also called as the soil moisture characteristic or the capillary pressuresaturation curve. The effect of water stress depends on the respective flows duration of the deficit period and the plant's adaptation mechanism. Water stress has both direct and indirect influence on photosynthesis and on plant growth (Raviv and Blom, 2001).

Corresponding Author: Noordin Wan Daud, Department of Crop Science, Faculty of Agriculture, University Putra Malaysia, 43400 UPM Serdang, Selangor, Malaysia e-mel:wnordin@agri.upm.edu.my 
According to USDA soil taxonomy, Munchong series has been classified as very fine, Typic Hapludox. In the FAO/UNESCO Legend, this soil has been classified Haplic Ferralsol. Munchong series soil is a silty clay loam to silty clay with yellowish brown to strong brown. The structure of this soil series is moderate to strong fine and medium sub-angular blocky. This soil has been classified in first class soil for rubber planting in term of soil-crop suitability (Malaysian Rubber Board, 2009).

\section{MATERIALS AND METHODS}

Plant materials and experimental treatments: This study was carried out under rain shelter at Field two, University Putra Malaysia, Serdang, Selangor, Malaysia. Two latex timber clones from Malaysia Rubber Board (MRB), RRIM 2025 and RRIM 3001 were used as planting materials in this study. The seedlings (budded plant) used were at three months stages. The polythene bags with the size of 18 inch $\times 20$ inch which can fit the planting media up to $10 \mathrm{~kg}$ were used in this study. The bags were provided with perforations for drainage, filled with good, friable surface soil which was free of roots, stones and clods. Media used were soil from Munchong series which have been classified as first class soil for rubber. RISDA 1 fertilizer which contains $10 \% \mathrm{~N}, 16 \% \mathrm{P}, 9 \%$ $\mathrm{K}$ and $2.5 \% \mathrm{Mg}$ were used as source of fertilizer. RISDA 1 was used widely by rubber planters in Malaysia since it's recommended by Rubber Industry Smallholders Development Authority. Recommended rate were used in this study because another study about fertilizer on Latex Timber Clones has proved rubber plants will scorched and dead if overfertilized (Shafar and Noordin, 2011).

Fertilizer was applied to the plants one month after transplanting. Fertilizer was applied manually $30 \mathrm{~g}$ per plant. There were two clones which, consisting of five treatments per clone. Treatments one to five (T1 until T5) were from RRIM 3001 clone, while treatments 610 (6 until T10) were of clone RRIM 2025. Water treatment frequency by day was applied. Treatments comprised the control as well-watered (1 and T6), watering every two days ( 2 and T7), every five days (3 and T8), every 10days (4 and T9) and every 15 days (5 and T10). The duration of this study is six week. At the last week, all plants in severe stress treatment were dead due to water stress treatment.

Water requirement determination: Since the plant in this study were planted in polythene bag (limited region), the availability water were used as water requirement for these treatments. In order to get water availability, principle of water retention was used.
Water retention of the soil was measured using a pressure chamber and the pressure plate. A core ring measuring about 7.6 and $4.0 \mathrm{~cm}$ in diameter and depth, respectively and having known weight was hammered into the soil to ring depth. The samples retaining rings placed on each of the four porous plates for 1, 10, 33 and $1500 \mathrm{kPa}$ pressure. The core (undisturbed) samples was broke up into five pieces of equal sizes. One piece of sample in retaining ring placed on each of the porous plates. For the 0 bar pressure (saturation), the samples is placed in a retaining ring on a coarse wire mesh. All ceramic plates were saturated for 24 hours by keeping the water level just below the edge of the ring. The plates with samples placed inside the corresponding pressure chamber. The plate connected to the outflow tube. The chamber was closed and pressure applied. Equilibrium was attained when no more outflows occurs. A period of 4-7 days is usually sufficient to achieve moist soil. The chamber opened, the samples removed and each of them was weighed (Wa). The sample oven-dried at $105^{\circ} \mathrm{C}$ for 24 hours and each of the soil samples weighed again $(\mathrm{Wb})$. The calculation for volumetric water content was: $\left(\mathrm{m}^{3} \mathrm{~m}^{-3}\right), \theta \mathrm{v}=($ Wa$\mathrm{Wb}) / \mathrm{Wb} \times \rho_{\mathrm{b}}$, where $\rho_{\mathrm{b}}=$ bulk density, $\mathrm{Wa}=$ dry weight, $\mathrm{Wb}=$ oven dried sample after dry weight.

\section{Data collection:}

Height: plant height was measured from the soil level until the top of the plant shoot.

Girth: Girth circumference was measured $10 \mathrm{~cm}$ from the soil level.

Relative chlorophyll content: Data was taken using the chlorophyll meter SPAD-502. The Chlorophyll meter SPAD-502 was calibrated by pressing the measuring head closed without inserting the leaf.

Photosynthesis rate and stomata conductance: The rate of photosynthesis and stomata conductance had been measured by Portable Photosynthesis System Model LICOR-6200. The fully expanded leaves were selected to measure the photosynthesis rate and stomata conductance.

Experimental design and data analysis: The study was conducted in a completely randomized block design with four replications. Each block comprised of 30 plants and each treatment consists of three samples (polythene bags). There were two clones which consisting of five treatments per clone. Analysis Of Variance (ANOVA) on data obtained was performed using Statistical Analysis System (SAS 9.1, SAS Institute, Inc. Cary NC. USA). Least Significant Different (LSD) test at $\mathrm{p}<0.05$ was employed for mean comparison. 
Am. J. Applied Sci., 8 (3): 206-211, 2011

\section{RESULTS}

Water requirement determination: Figure 1 shows with increasing soil suction, the soil becomes progressive drier in a non-linear manner.

Growth responses: The plant height showed significant difference at level $\mathrm{p}=0.05$ between treatments and comparison using LSD (Fig. 2). Comparison between clones showed RRIM 2025 had significantly changes in plant height measurements (6T7) compared to RRIM 3001 (1-2).

The well watered treatment ( 1 and T6) showed the highest value of girth measurement (Fig. 3). This result showed that girth increment decrease in relation to increasing of water stress.

Table 1 shows the dry weight of each part of the plant, leaf, stem and root. From this table, it can be concluded that water stress influence the partitioning in the plant system. Treatments 1, 2, 6 and T7 showed increase of partitioning in stem, while there was decrease in carbon partitioning in root and leaves. Well watered treatment, T6 showed that the most balance source and sink relationship of photosynthesis between leaves, stem and root.

Physiological responses: Table 2 shows the measurement of photosynthesis rate and stomata conductance at light quantum range 800-1000 and chlorophyll content. Photosynthesis rate showed variation among the treatments. Compared to clone RRIM 2025 (6-T7) and RRIM 3001 (1-T2), the photosynthesis rate was higher in clone RRIM 3001 than in clone RRIM 2025. In other treatments, there was no photosynthesis rate data obtained because the plants almost die due to water stress condition and data could not be taken.

Stomata conductance was high in well-watered treatments (1 and T6). T6 showed the highest value of stomata conductance. Plants with every two days watering (2 and T7) showed lower value than well watered.

Table 2 also showed that the chlorophyll content decreased with decreasing of water availability. Well watered treatment (T6) showed the highest chlorophyll content among treatments follow by 7, 1, 2, 3 and T8; while for others, there no value recorded because the plants wilted and the leaves fell due to extreme water stress. Comparing among the clones, clone RRIM 2025 showed higher chlorophyll content compared to clone RRIM 3001.

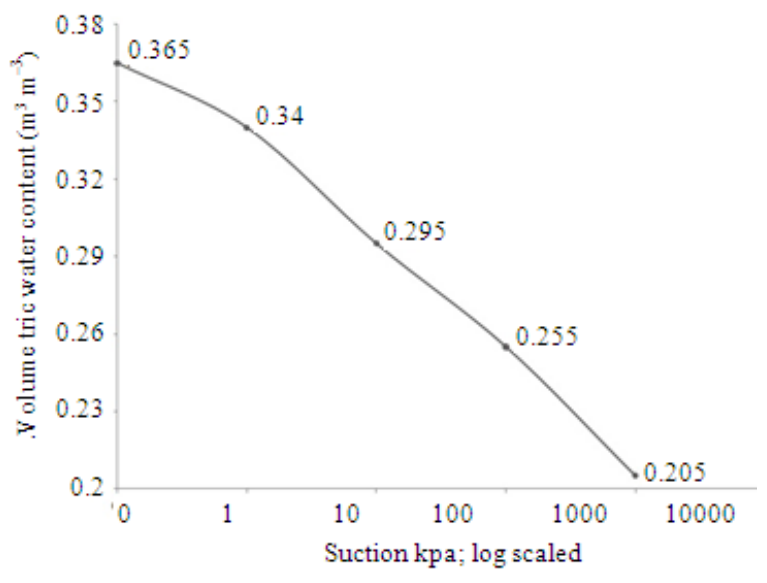

Fig. 1: Soil water retention curve

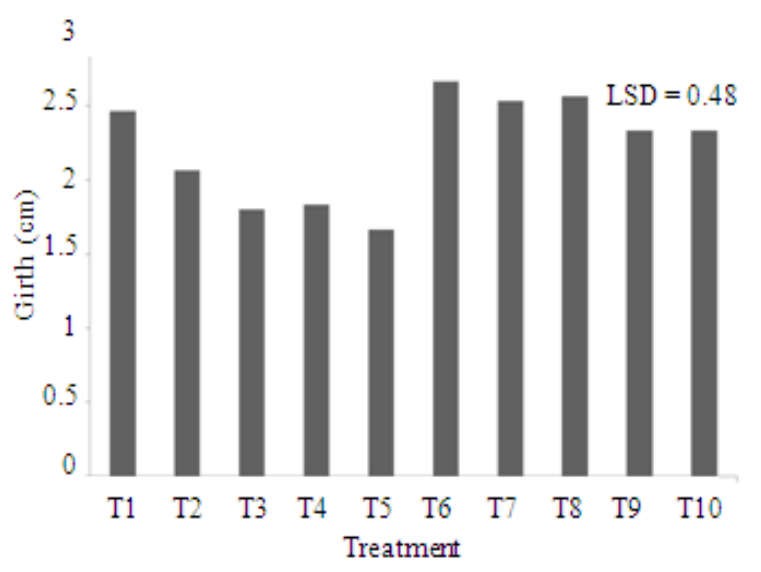

Fig. 2: Plant height due to different water regimes

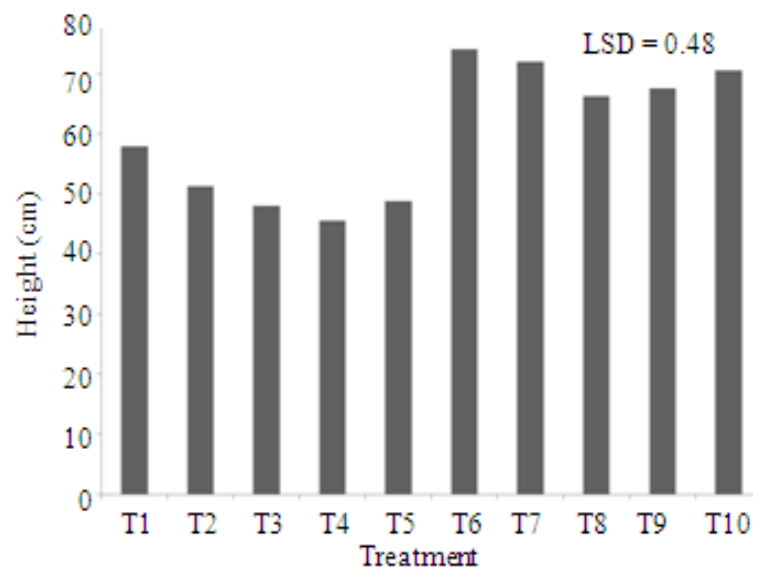

Fig. 3: Plant girth circumference due to different water regimes 
Am. J. Applied Sci., 8 (3): 206-211, 2011

Table 1: Dry weight of rubber plant after treatment

\begin{tabular}{|c|c|c|c|}
\hline Treatment & $\begin{array}{l}\text { Leaf dry } \\
\text { weight }(\mathrm{g})\end{array}$ & $\begin{array}{l}\text { Stem dry } \\
\text { weight }(\mathrm{g})\end{array}$ & $\begin{array}{l}\text { Root dry } \\
\text { weight }(\mathrm{g})\end{array}$ \\
\hline \multicolumn{4}{|l|}{ RRIM 3001} \\
\hline $\begin{array}{l}\text { Well-watered } \\
\text { (T1) }\end{array}$ & $6.84 a$ & $7.56 \mathrm{a}$ & $15.65 b$ \\
\hline RRIM 3001 & & & \\
\hline $\begin{array}{l}\text { Water every two days } \\
\text { (T2) }\end{array}$ & $6.78 \mathrm{a}$ & $6.51 \mathrm{ab}$ & $20.38 \mathrm{ab}$ \\
\hline $\begin{array}{l}\text { RRIM } 3001 \\
\text { Water every five days }\end{array}$ & & & \\
\hline $\begin{array}{l}\text { (T3) } \\
\text { RRIM } 3001\end{array}$ & $0.00 \mathrm{c}$ & $2.96 \mathrm{bc}$ & $19.76 \mathrm{ab}$ \\
\hline $\begin{array}{l}\text { Water every } 10 \text { days } \\
\text { (T4) } \\
\text { RRIM } 3001\end{array}$ & $0.00 \mathrm{c}$ & $2.00 \mathrm{c}$ & $17.36 \mathrm{~b}$ \\
\hline $\begin{array}{l}\text { Water every } 15 \text { days } \\
\text { (T5) } \\
\text { RRIM } 2025\end{array}$ & $0.00 \mathrm{c}$ & $1.00 \mathrm{c}$ & $15.97 \mathrm{~b}$ \\
\hline $\begin{array}{l}\text { Well watered } \\
\text { (T6) } \\
\text { RRIM } 2025\end{array}$ & $8.77 \mathrm{a}$ & $10.70 \mathrm{a}$ & $20.90 \mathrm{ab}$ \\
\hline $\begin{array}{l}\text { Water every two days } \\
\text { (T7) } \\
\text { RRIM } 2025\end{array}$ & $6.07 \mathrm{ab}$ & $9.86 a$ & $18.93 b$ \\
\hline $\begin{array}{l}\text { Water every five days } \\
\text { (T8) } \\
\text { RRIM } 2025\end{array}$ & $2.43 b c$ & 7.30ab & $23.34 \mathrm{ab}$ \\
\hline $\begin{array}{l}\text { Water every 10days } \\
\text { (T9) } \\
\text { RRIM } 2025\end{array}$ & $0.00 \mathrm{c}$ & $1.80 \mathrm{c}$ & $29.87 \mathrm{a}$ \\
\hline $\begin{array}{l}\text { Water every } 15 \text { days } \\
\text { (T10) }\end{array}$ & $0.00 \mathrm{c}$ & $1.30 \mathrm{c}$ & $20.31 \mathrm{ab}$ \\
\hline $\mathrm{LSD}_{0.05}$ & 4.17 & 4.37 & 10.28 \\
\hline
\end{tabular}

Values in each column with same letter did not differ significantly at $\mathrm{p}<0.05$ according to LSD

Table 2: Physiological response of rubber plant under water stress condition

\begin{tabular}{lccc}
\hline Treatment & $\begin{array}{c}\text { Photosynthesis rate } \\
\left(\mu \mathrm{mol} \mathrm{m}^{-2} \mathrm{~s}^{-1}\right)\end{array}$ & $\begin{array}{c}\text { Stomata } \\
\text { conductance }\end{array}$ & $\begin{array}{c}\text { Chlorophyll content } \\
\left(\mu \mathrm{mol} \mathrm{m} \mathrm{m}^{-2}\right)\end{array}$ \\
\hline $\mathrm{T} 1$ & $2.74 \mathrm{a}$ & $0.16 \mathrm{ab}$ & $47.53 \mathrm{a}$ \\
$\mathrm{T} 2$ & $3.16 \mathrm{a}$ & $0.07 \mathrm{bc}$ & $45.93 \mathrm{a}$ \\
$\mathrm{T} 3$ & $0.00 \mathrm{c}$ & $0.00 \mathrm{c}$ & $0.00 \mathrm{c}$ \\
$\mathrm{T} 4$ & $0.00 \mathrm{c}$ & $0.00 \mathrm{c}$ & $0.00 \mathrm{c}$ \\
$\mathrm{T} 5$ & $0.00 \mathrm{c}$ & $0.00 \mathrm{c}$ & $0.00 \mathrm{c}$ \\
$\mathrm{T} 6$ & $2.05 \mathrm{ab}$ & $0.22 \mathrm{a}$ & $51.47 \mathrm{a}$ \\
$\mathrm{T} 7$ & $0.89 \mathrm{bc}$ & $0.00 \mathrm{c}$ & $50.40 \mathrm{a}$ \\
$\mathrm{T} 8$ & $0.00 \mathrm{c}$ & $0.00 \mathrm{c}$ & $12.67 \mathrm{~b}$ \\
$\mathrm{~T} 9$ & $0.00 \mathrm{c}$ & $0.00 \mathrm{c}$ & $0.00 \mathrm{c}$ \\
T10 & $0.00 \mathrm{c}$ & $0.00 \mathrm{c}$ & $0.00 \mathrm{c}$ \\
LSD $_{0.05}$ & 1.17 & 0.14 & 12.58 \\
\hline $\mathrm{V}_{25}$ &
\end{tabular}

Values in each column with same letter did not differ significantly at $\mathrm{p}<0.05$ according to LSD

\section{DISCUSSION}

Water requirement determination: Available water capacity is the range of available water that can be stored in the soil and be available for growing crops.

From Fig. 1, it is shown that the volume water content at saturation, field capacity and permanent wilting points are $0.37,0.34,0.34,0.26$ and 0.21 $\mathrm{m}^{3} \mathrm{~m}^{-3}$, respectively. The available water content for plant use is the differences between permanent wilting point and field capacity, which is $0.26-0.21=0.05$ $\mathrm{m}^{3} \mathrm{~m}^{-3}$. This means that the amount of water used for $10 \mathrm{~kg}$ of Munchong series soil in every watering is $0.5 \mathrm{~L}$.

Growth responses: From Fig. 2, the results indicate that clone RRIM 2025 is more resistant to water stress compared to RRIM 3001. This result also shows that plants grow vigorously when it gets enough water, while in water stress condition it will inhibits growth and leads the plant to die. At the initial phase of plant growth and establishment of vegetative part, water stress is a very important limiting factor (Shao et al., 2008).

The water stress condition in rubber will results in significantly smaller change in stem diameter (Maren et al., 2008). The increasing of water frequency will reduces water availability in plant. This will affect the source and sink relationship and also assimilate partitioning in plant.

Most of the plant dry matter was the result of photosynthesis (carbon end product) and percentage of dry matter showed assimilate partitioning of photosynthesis in part of plant (leaf, stem and root) (Daie, 1985). This shows that when there is a reduction of carbon source to sink in the plant, there is no source and sink relationship occurs during plant stress condition. During water stress condition, dry matter translocation was affected. Water stress frequently enhanced allocation of dry matter to the root, which will enhance the water uptake (Leport et al., 2006).

Physiological responses: Photosynthesis does not limit growth, but the limited growth interferes with photosynthesis, which decrease water availability resulting in decrease of photosynthesis in plant. Under water stress condition, the photosynthesis pigments and components will change, damage and activities of Calvin cycle enzymes will be diminished (Zhao et al., 2010; Anjum et al., 2003; Monakhova and Chernyadev, 2002; Fu and Huang, 2001).

The reductions on stomata conductance of guard cells force the stomata to close, so that it will reduce the transpiration rate and photosynthesis rate. The effect of water stress on stomata conductance showed in T3, T4, T5, T8, T9 and T10 indicated the failure of stomata closure to recover upon rewatering (Vijayakumar et al., 1997).

From this study, it showed that different water regimes will induce water stress and decrease chlorophyll content. These will results reduction of the number of chloroplast in the stressed leaves (Boamah et al., 2011; Arunyanark et al., 2009). Consequently, 
the nutrients uptake from the soil and root will be reduced as it needs water as a medium to transport the nutrient to the leaf. Water stress also will reduce the lifespan of leaves (Rao et al., 1990). This will cause accelerated senescence and consequently chlorophyll degradation.

\section{CONCLUSION}

Rubber plants exhibit a variety of responses to different water regimes, which are depicted by symptomatic and quantitative changes in growth and morphology. The ability of rubber plants to cope with the water stress varies across and within clones. Economic viability, patterns of assimilates partitioning, growth are highly adversely affected. Other notable water stress effect from this study include photosynthesis rate via stomata conductance and chlorophyll contents. There were various responses found in clones 2025 and RRIM 3001 under water stress. Treatment with well-watered for clone RRIM 2025 (T6) had highest value than other treatments. There were treatments failed to adapt to water stress at treatments every five days, followed by every 10 days and every 15 days watering frequency. This study found that rubber clones RRIM 2025 and RRIM 3001 were not suitable for planting in dry areas.

\section{ACKNOWLEDGEMENT}

The researchers would like to thank Universiti Putra Malaysia for the post-graduate grant and also the Ministry of Science, Technology and Innovation, Malaysia, for the research grant, Fundamental Research Grant Scheme (FRGS), No 01-11-08-665FR, in supporting the research work.

\section{REFERENCES}

Anjum, F., M. Yaseen, E. Rasul, A. Wahid and S. Anjum, 2003. Water stress in barley (Hordeum Vulgare L.). II: Effect on chemical composition and chlorophyll content. Pak. J. Agric. Sci., 40: 45-49.

Arunyanark, A., S. Jogloy, N. Vorasoot, C. Akkasaeng, T. Kesmala and A. Patanothai, 2009. Stability of relationship between chlorophyll density and soil plant analysis development chlorophyll meter readings in peanut across different drought stress conditions. Asian J. Plant Sci., 8: 102-110.

Boamah, P.O., J.D. Owusu-Sekyere, L.K. Sam-Amoah and B. Anderson, 2011. Effect of irrigation interval on chlorophyll fluorescence of tomatoes under sprinkler. Asian J. Agric. Res., 5: 83-89. DOI: 10.3923/ajar.2011.83.89
Daie, J., 1985. Carbohydrate Partitioning and Metabolism in Crops. Hortic. Rev., 7: 69-108.

Fan, X. and F. Zhang, 2000. Soil Water, Fertility and sustainable agricultural production in arid and semiarid regions on the loess plateau. J. Plant Nutr. Soil Sci., 163: 107-113. DOI: 10.1002/(SICI)15222624(200002)163:1<107::AID-JPLN107>3.0.CO;2-W

$\mathrm{Fu}, \mathrm{J}$. and B. Huang, 2001. Involvement of antioxidants and lipid peroxidation in the adaptation of two cool-season grasses to localized drought stress. Environ. Exp. Bot., 45: 105-114. DOI: 10.1016/S0098-8472(00)00084-8

Fuller, A.C. and M.O. Harhay, 2010. Population growth, climate change and water scarcity in the southwestern united states. Am. J. Environ. Sci., 6: 249-252. DOI: 10.3844/ajessp.2010.249.252

Gholizadeh, A., M.S.M. Amin, A.R. Anuar, M. Esfahani and M.M. Saberioon, 2010. The study on the effect of different levels of Zeolit and water stress on growth, development and essential oil content of moldavian balm (Dracocephalum moldavica L.). Am. J. Applied Sci., 7: 33-37. DOI: 10.3844/ajassp.2010.33.37

Leport, L., N.C. Turner, R.J. French, M.D. Barr and R. Duda et al., 2006. Physiological responses of chickpea genotypes to terminal drought in a Mediterranean-type environment. Eur. J. Agronomy. 11: 279-291. DOI: 10.1016/S11610301(99)00039-8

Malaysian Rubber Board, 2009. Rubber Plantation and Processing Technologies. Malaysian Rubber Board. http://vital.lgm.gov.my/vital/access/manager/Colle ction/vital1:78300;jsessionid=ED57218D35C06B A5D87A673B74480277

Maren, E.V.B., T.R. Dennis and B.M. William, 2008. Water-stress-induced changes in resin and rubber concentration and distribution in greenhousegrown Guayule. Am. Soc. Agronomy, 98: 766-773.

Mirakhori, M., F. Paknejad, F. Moradi, M. Ardakani and H. Zahedi et al., 2009. Effect of drought stress and methanol on yield and yield components of soybean max (L 17). Am. J. Biochem. Biotechnol., 5: 162-169. DOI: 10.3844/ajbbsp.2009.162.169

Monakhova, O.F. and I.I. Chernyadev, 2002. Protective role of kartolin-4 in wheat plants exposed to soil draught. Appl. Biochem. Micro, 38: 378-380. DOI: 10.1023/A:1016243424428

Rao, G.G., P.S. Rao, R. Rajagopal, A.S. Devakumar and K.R. Vijayakumar et al., 1990. Influence of soil, plant and meteorological factors on water relations and yield in Hevea brasiliensis. Int. J. Biometeorol., 34: 175-180. DOI: 10.1007/BF01048717 
Raviv, M. and T.J. Blom, 2001. The effect of water availability and quality on photosynthesis and productivity of soilless-grown cut roses. Sci. Horticulturae, 88: 257-276. DOI: 10.1016/S03044238(00)00239-9

Sajedi, N.A., M.R. Ardakani, A. Naderi, H. Madani and M.M.A. Boojar, 2009. Response of maize to nutrients foliar application under water deficit stress conditions. Am. J. Agric. Biol. Sci., 4: 242-248. DOI: 10.3844/ajabssp.2009.242.248

Schindler, U., J. Steidl, L. Müller, F. Eulenstein and J. Thiere, 2007. Drought risk to agricultural land in northeast and central Germany. J. Plant Nutr. Soil Sci., 170: 357-362. DOI: 10.1002/jpln.200622045

Shafar, J.M. and W.D. Noordin, 2011. Evaluation of straight fertilizer, urea (AGRENAS) and ammonium sulphate, on Hevea brasiliensis (RRIM2000). J. Sci. Technol. Trop., 7: 1-7.

Shao, H.B, L.Y. Chu, C.H. Jaleel and C.H. Zhao, 2008. Water-deficit stress-induced anatomical changes in higher plants. Comput. Rendus Biol., 331: 215-225. DOI: 10.1016/j.crvi.2008.01.002
Veihmeyer, F.J. and A.H. Hendrickson, 1927. The Relation of Soil Moisture to Cultivation and Plant Growth. Proc. Int. Congor. Soil Sci., 3: 498-513.

Vijayakumar, K., R. Dey, S.K. Chandrasekhar, T.R. Devakumar and A.S. Mohankrishna et al., 1997. Irrigation requirement of rubber tree (Hevea brasiliensis) in the subhumid tropics. Water Manage., 35: 245-259. DOI: 10.1016/S03783774(97)00019-X

$\mathrm{Xu}, \mathrm{Z} . Z$. and Z.W. Yu, 2006. Nitrogen metabolism in flag leaf and grain of wheat in response to irrigation regimes. J. Plant Nutr. Soil Sci., 169: 118-126. DOI: 10.1002/jpln.200420418

Zhao, D., B. Glaz and J.C. Comstock, 2010. Sugarcane response to water-deficit stress during early growth on organic and sand soils. Am. J. Agric. Biol. Sci., 5: 403-414. DOI: 10.3844/ajabssp.2010.403.414 